\title{
TIMS analysis of neodymium isotopes in human tooth enamel using $\mathbf{1 0}^{13}$ $\Omega$ amplifiers
}

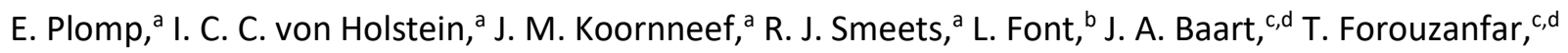
and G. R. Davies ${ }^{a}$

a Department of Earth Sciences, Vrije Universiteit Amsterdam, de Boelelaan 1085, 1081 HV, Amsterdam, The Netherlands.E-mail: e.plomp@vu.nl

${ }^{b}$ Elsevier Spain, S.L., Av. Josep Tarradellas, 20-30, 19 Planta, 08029 Barcelona, Spain

${ }^{\mathrm{C}}$ Department of Oral and Maxillofacial Surgery/Oral Pathology, VU University Medical Center (VUMC), De Boelelaan 1117, 1081 HV Amsterdam, The Netherlands

${ }^{\mathrm{d}}$ Academic Centre for Dentistry Amsterdam (ACTA), Gustav Mahlerlaan 3004, 1081 LA Amsterdam, The Netherlands

This is the author's version of the work. It is posted here only for personal use, not for redistribution and/or commercial use. The definitive version is published in Journal of Analytical Atomic Spectrometry:

Plomp, E., I.C.C. von Holstein, J.M. Koornneef, R.J. Smeets, L. Font, J.A. Baart, T. Forouzanfar and G.R. Davies 2017. TIMS analysis of neodymium isotopes in human tooth enamel using $1013 \Omega$ amplifiers, Journal of Analytical Atomic Spectrometry, 2391-2400.

https://doi.org/10.1039/C7JA00312A

Human provenance studies employing isotope analysis are essential in archaeological and forensic sciences but current applications provide limited spatial resolution. This study reports on the potential of neodymium isotope composition $\left({ }^{143} \mathrm{Nd} /{ }^{144} \mathrm{Nd}\right)$ to improve human provenancing capabilities. Human tissues contain very low ( $<0.1 \mathrm{ppm}$ ) neodymium concentrations, such that previous composition analysis was not possible. Additionally, Nd composition analysis in human enamel is hindered by Ca in the sample matrix. A modified $\mathrm{Nd}$ chromatographic separation technique is reported here, which removes large $\mathrm{Ca}$ quantities and accommodates large sample sizes (300-1000 mg). Verification of the modified chromatographic procedure was achieved using an internal synthetic tooth standard. These advancements allow for high precision $\mathrm{Nd}$ isotope composition analysis on $\sim 500 \mathrm{mg}$ of tooth enamel, or $>100 \mathrm{pg}$ of $\mathrm{Nd}$, by thermal ionization mass spectrometry (TIMS) using $10^{13} \Omega$ resistors. Neodymium concentrations in enamel from third molars of modern Dutch residents range between 0.1-21.0 ppb $(\mathrm{n}=$ 23). The ${ }^{143} \mathrm{Nd} /{ }^{144} \mathrm{Nd}$ values for Amsterdam $(0.51204-0.51259, \mathrm{n}=12)$ and Rotterdam (0.51187-0.51239, $\mathrm{n}=8$ ) are significantly different ( $P$ value $=0.02$ ), demonstrating the potential of neodymium isotope composition to provide improved spatial resolution. Further assessment of $\mathrm{Nd}$ composition in enamel of residents from other geological contexts is required to better understand the human provenance capabilities of neodymium. 


\section{Introduction}

Isotope analysis of human remains is used in the investigation of human mobility in forensic ${ }^{1,2}$ and archaeological contexts. ${ }^{3-6}$ These analyses centre on the principle that the isotopic values of the environment are reflected in the hair, skeletal and dental tissues of an individual. Tooth enamel is preferentially used for analysis as it is resistant to post-mortem alteration, in contrast to bone. ${ }^{7}$ Tooth enamel mineralises during childhood and adolescence ${ }^{8}$ and thereby preserves the isotope signatures of an individual's early years. The most commonly used isotopic systems for human provenancing are strontium $\left({ }^{87} \mathrm{Sr} /{ }^{86} \mathrm{Sr}\right)$, oxygen $\left(\delta^{18} \mathrm{O}\right)$ and, less often, lead $\left({ }^{206} \mathrm{~Pb} /{ }^{204} \mathrm{~Pb},{ }^{207} \mathrm{~Pb} /{ }^{204} \mathrm{~Pb},{ }^{208} \mathrm{~Pb} /{ }^{204} \mathrm{~Pb},{ }^{208} \mathrm{~Pb} /{ }^{206} \mathrm{~Pb}\right.$, ${ }^{207} \mathrm{~Pb} /{ }^{206} \mathrm{~Pb}$ ). Isoscapes, maps that predict the bioavailable isotopic abundance ratios, have been constructed for $\mathrm{O}$ and $\mathrm{H}^{9} \mathrm{Sr}^{10,11}$ and $\mathrm{Pb}^{12,13}$ for several countries in order to pinpoint the origins of humans.

There are still limitations that restrict the interpretation of mobility patterns, despite the widespread application of these isotopic systems. The primary source of radiogenic isotope abundance ratios is assumed to be of geological origin, however, non-geological sources can also contribute to the isotopic composition of bones and teeth. In the $\mathrm{Pb}$ system, anthropogenic sources (such as exposure from mining and smelting, battery manufacture, and lead based paints) may overwrite geological signatures, ${ }^{14}$ while bioavailable $\mathrm{Sr}$ can be affected by marine-derived aerosols. ${ }^{15}$ Furthermore, distinguishing between similar geological environments using a single isotopic system remains impossible. ${ }^{15}$ These complications affect the interpretation of the isotopic results and it has previously been stressed that a multi-isotope approach is required to better constrain provenance..$^{1,4,5}$

The power of a multi-isotope approach can be extended with the addition of a new isotope system. One such candidate is neodymium $\left({ }^{143} \mathrm{Nd} /{ }^{144} \mathrm{Nd}\right)$. The ${ }^{147} \mathrm{Sm}-{ }^{143} \mathrm{Nd}$ decay system has been widely applied in the Earth and Planetary Sciences for geochronology and has proved particularly successful in determining the provenance of igneous and sedimentary rocks (see Dickin ${ }^{16}$ for an overview), and paleoseawater. ${ }^{17-19}$ Furthermore, neodymium has been used to investigate changing climatic conditions related to differential erosion rates and mechanisms $\mathrm{s}^{20-22}$ and to assess diagenesis in fossils. ${ }^{23,24}$ The potential of $\mathrm{Nd}$ as a provenance indicator was demonstrated by $\mathrm{Nd}$ isotope composition found in modern animal bones, which was in accordance to underlying bedrock or ambient water. ${ }^{23}$ Moreover, neodymium isotope composition has been successfully used to provenance archaeological artefacts. ${ }^{25-27}$

Despite its potential for provenance studies, neodymium isotope analyses are yet to be applied to human remains due to: i) problems caused by diagenesis following long term burial of bones, ${ }^{23,24}$ and ii) low concentrations ( $<1 \mathrm{ppm}$ ) of $\mathrm{Nd}$ in human ${ }^{22}$ and animal teeth. ${ }^{23,24}$ Nevertheless, $\mathrm{Nd}$ isotopes could provide valuable complementary provenance information because of its different geochemical characteristics compared to other isotopes used for provenance purposes. In contrast to the $\mathrm{Rb}-\mathrm{Sr}$ isotope system, which experiences parent daughter elemental fractionation during mineral break down, neodymium has limited mobility during weathering processes and, therefore, bioavailable ${ }^{143} \mathrm{Nd} /{ }^{144} \mathrm{Nd}$ provides a better representation of the bedrock compositions than $\mathrm{Sr}^{20,23}$ Additionally, the $\mathrm{Nd}$ of oceanic basins provides a greater reflection of surrounding geology, due to the shorter residence time of $\mathrm{Nd}$ in the ocean than $\mathrm{Sr}^{18,28}$ This observation may prove advantageous in coastal regions due to the reduced 
sea-spray effect of the $\mathrm{Nd}$ isotope system. The goal of this study was therefore to: (1) develop a technique to reliably analyse $\mathrm{Nd}$ isotopes in human tooth enamel despite low elemental abundance; (2) provide a preliminary assessment of the practicality of its use for human provenance studies.

\section{Neodymium isotopes}

Neodymium is a light rare earth element (LREE) of the lanthanide series. Variations in Nd isotope composition of rocks are dependent on the time of formation, and the $\mathrm{Sm} / \mathrm{Nd}$ ratio which is dependent on the rock type and tectonic setting in which they formed. ${ }^{22,29}$ The surface of the Earth has ${ }^{143} \mathrm{Nd} /{ }^{144} \mathrm{Nd}$ abundance ratios between 0.510 for Archaean continental crust and 0.514 for mid-ocean ridge basalts. ${ }^{16}$ Conventionally, $\mathrm{Nd}$ isotope composition is expressed in the epsilon notation $(\varepsilon \mathrm{Nd})$ where ${ }^{143} \mathrm{Nd} /{ }^{144} \mathrm{Nd}$ ratios are compared to the chondritic uniform reservoir (CHUR), which represents the bulk Earth Nd isotope composition based on an assessment of chondritic meteorites. The accepted present day chondritic value is $0.512638^{30}$ and $\varepsilon N d$ is calculated according to Eq. (1):

$\left.\varepsilon N d=\left[\left({ }^{143} \mathrm{Nd} /{ }^{144} \mathrm{Nd}\right)_{\text {sample }} /\left({ }^{143} \mathrm{Nd} /{ }^{144} \mathrm{Nd}\right)_{\text {CHUR }}\right)-1\right] \times 10^{4}$

$\varepsilon N d$ values can be as low as -56 in old crustal rocks, while young magmatic rocks have high $\varepsilon N d$ values up to $+15 .{ }^{16}$ Detailed mapping of variation in geological $\mathrm{Nd}$ isotope composition is, however, limited (but see Jeandel et al. ${ }^{18}$ and and Brems et al. ${ }^{26}$ ).

Neodymium is transferred from the geology to bodies of water and vegetation, and enters the human body through diet, where $\mathrm{Nd}$ substitutes $\mathrm{Ca}$ in the enamel of human teeth. ${ }^{31}$ Due to its relatively heavy mass, it is assumed that $\mathrm{Nd}$ isotopes do not undergo any significant mass-dependent isotopic fractionation within the environment and human body. ${ }^{22,23}$ Coupled with the conservative behaviour of REE during weathering, ${ }^{32}$ this means that dietary $\mathrm{Nd}$ isotope composition within teeth is unaltered along the food chain or during biomineralisation, and should therefore reflect the values of the diet of an individual, and in turn also the local bioavailable $\mathrm{Nd}$. The biological and physiological functions of $\mathrm{Nd}$ are, however, not fully understood because studies on $\mathrm{Nd}$ in biological systems are very limited due to low $\mathrm{Nd}$ concentrations in human tissues ( $<0.7 \mathrm{ppm}$, Table 1 ). Neodymium, similar to other REE, has no physiological function in humans ${ }^{31}$ and large quantities of $\mathrm{Nd}$ can be toxic to the human body. ${ }^{31,33}$ Elevated $\mathrm{Nd}$ concentrations in lung tissues ( $>50 \mathrm{ppb})$, urine $(>4 \mathrm{ppb})$ and hair ( $>160 \mathrm{ppb})$, are found in individuals with occupations that involved contact with REEs, ${ }^{34,35}$ which suggests that $\mathrm{Nd}$ is additionally accumulated within the human body by inhalation of dust or through dermal contact. 
Table $1 \mathrm{Nd}$ concentrations in tissues from healthy human individuals that were not directly associated with mining areas or professions involving contact with REEs.

\begin{tabular}{|c|c|c|c|c|c|c|}
\hline Tissue Type & $\begin{array}{l}\text { Range } \\
\text { (ppb) }\end{array}$ & $\begin{array}{l}\text { Mean Nd } \\
\text { content } \\
\text { (ppb) }\end{array}$ & \pm SD & $\mathbf{n}$ & Country & Reference \\
\hline Hair & $41-789$ & 134 & 30 & 41 & $\begin{array}{r}\text { Baotou city, China } \\
\text { (N) }\end{array}$ & Wei et al. ${ }^{34}$ \\
\hline Hair & $0.0-0.3$ & 0.1 & & 30 & $\begin{array}{l}\text { Dong and Ping Vil- } \\
\text { lage, China (S) }\end{array}$ & Tong et al. ${ }^{36}$ \\
\hline Hair & $7.8-9.4$ & 8.7 & 0.5 & 3 & China & Ming and Bing ${ }^{37}$ \\
\hline Hair & $60-890$ & 480 & 590 & 12 & $\begin{array}{r}\text { Hetian town, China } \\
\text { (SE) }\end{array}$ & Li et al. ${ }^{38}$ \\
\hline Nail & $35-500$ & 275 & 233 & 4 & Italy (N) & Pietra et al. ${ }^{35}$ \\
\hline Bone (rib) & $1-62$ & 11 & 9 & 80 & Obninsk, Russia & Zaichick et al. $^{39}$ \\
\hline Lung & $11-88$ & 46 & 31 & 11 & Italy $(\mathrm{N})$ & Pietra et al. ${ }^{35}$ \\
\hline Lymph nodes & & 118 & & 7 & Italy (N) & Vocaturo et al. ${ }^{40}$ \\
\hline $\begin{array}{l}\text { Laryngeal } \\
\text { tissues }\end{array}$ & & 96 & 9 & 15 & Italy & Collecchi et al. ${ }^{41}$ \\
\hline Blood & $<1-<8$ & $<1.5$ & & 4 & Italy (N) & Pietra et al. ${ }^{35}$ \\
\hline Blood & $\begin{array}{r}2840- \\
3980 \\
\end{array}$ & 3370 & 420 & 5 & Nagoya City, Japan & $\begin{array}{l}\text { Inagaki and Haragu- } \\
\text { chii }^{42}\end{array}$ \\
\hline Blood & $\begin{array}{l}425- \\
1275 \\
\end{array}$ & 690 & 254 & 12 & $\begin{array}{r}\text { Hetian town, China } \\
\text { (SE) }\end{array}$ & Li et al. ${ }^{38}$ \\
\hline Plasma & & 28 & 1 & 5 & Italy $(\mathrm{N})$ & Esposito et al. ${ }^{43}$ \\
\hline Plasma & & 46 & 3 & 30 & Italy & Collecchi et al. ${ }^{41}$ \\
\hline Urine & $1.8-3.4$ & 2.7 & 1.6 & 4 & Italy (N) & Pietra et al. ${ }^{35}$ \\
\hline Kidney stone & $\begin{array}{r}60- \\
<3000\end{array}$ & $<112$ & & 10 & Vienna, Austria & Koeberl and Bayer ${ }^{44}$ \\
\hline Brain & $\begin{array}{l}<80- \\
<100\end{array}$ & $<100$ & & 1 & Vienna, Austria & Koeberl and Bayer ${ }^{44}$ \\
\hline
\end{tabular}

\section{Material}

Neodymium isotope analysis was performed on third molars (M3) donated by native Dutch inhabitants of the Netherlands (Fig. 1). The Netherlands is a low-lying (predominantly $<100 \mathrm{~m}$ ) mostly flat country in the northwest of Europe, with the south-western parts of the country formed by the estuary of three river systems: the Rhine, the Meuse, and the Scheldt (Fig. 1). The geology consists of Holocene deposits in the northwest, and Pleistocene areas in the south where there is more relief. ${ }^{45}$ The surface deposits comprise marine, fluvial and glacial sediments Quaternary of age (2.6 Ma-present). Locally these regions include loess and peat layers. ${ }^{46}$ Currently no regional $\mathrm{Nd}$ isoscape is available for this region and very limited background sampling has been performed in the Netherlands (see Table 2). For the purposes of this study, the total range of ${ }^{143} \mathrm{Nd} /{ }^{144} \mathrm{Nd}$ expected in human teeth is defined by the Rhine River sediment 
data range $\left({ }^{143} \mathrm{Nd} /{ }^{144} \mathrm{Nd}=0.511983\right.$ to $\left.0.512166, \mathrm{n}=18\right),{ }^{47,48}$ which is a general proxy for the total range of the Quaternary deposits in the Netherlands.

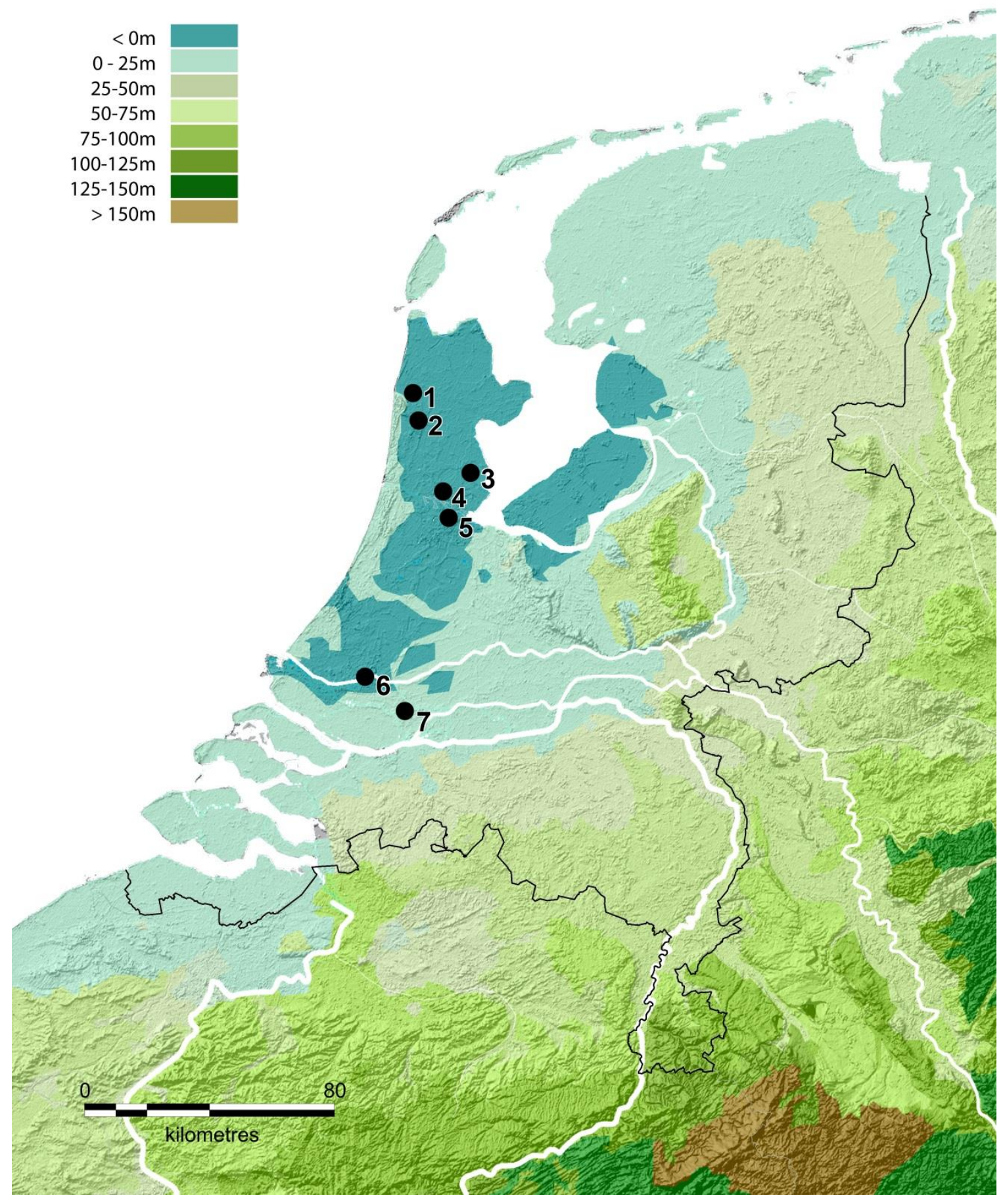

Fig. 1 A map of the Netherlands and localities where the individuals lived during formation of their third molars (modified from Kootker et al. ${ }^{49}$ ). 1 = Warmenhuizen, $2=$ Alkmaar, $3=$ Purmerend, $4=$ Zaandam, 5 = Amsterdam, 6 = Rotterdam, 7 = Dordrecht. 
Table 2 Background data set for the Netherlands and surrounding areas.

\begin{tabular}{|c|c|c|c|c|c|c|c|}
\hline Sample & $\mathbf{n}$ & Location & ${ }^{143} \mathrm{Nd} /{ }^{144} \mathrm{Nd}$ & Age & $\pm 2 \sigma$ & $\varepsilon N d$ & Reference \\
\hline $\begin{array}{l}\text { Enamel } \\
\text { (Mammoth) }\end{array}$ & 1 & $\begin{array}{l}\text { Rhine River, } \\
\text { Germany }\end{array}$ & 0.512288 & Late Pleistocene & 10 & -6.8 & Tütken et al. ${ }^{23}$ \\
\hline $\begin{array}{l}\text { Enamel } \\
\text { (Mammoth) }\end{array}$ & 1 & North Sea & 0.512408 & Late Pleistocene & 8 & -4.2 & Tütken et al. ${ }^{23}$ \\
\hline Sediment & 35 & North Sea & $\begin{array}{l}0.511579 \text { to } \\
0.512028\end{array}$ & Pliocene & & $\begin{array}{l}-20.7 \text { to } \\
-11.9\end{array}$ & Kuhlmann et al. ${ }^{48}$ \\
\hline Sediment & 16 & $\begin{array}{l}\text { Rhine River, } \\
\text { Netherlands }\end{array}$ & $\begin{array}{l}0,511983 \text { to } \\
0.512101\end{array}$ & Pliocene & & $\begin{array}{l}-12.8 \text { to } \\
-10.5\end{array}$ & Kuhlmann et al. ${ }^{48}$ \\
\hline Sediment & 2 & $\begin{array}{l}\text { Rhine River, } \\
\text { Netherlands }\end{array}$ & $\begin{array}{l}0.512159 \text { to } \\
0.512166\end{array}$ & Holocene & & $\begin{array}{l}-9.3 \text { to } \\
-9.1\end{array}$ & Bayon et al. ${ }^{47}$ \\
\hline Bone (fossil) & 10 & North Sea & $\begin{array}{l}0.512077 \text { to } \\
0512196\end{array}$ & Pleistocene & & $\begin{array}{l}-10.9 \text { to } \\
-4.2\end{array}$ & Tütken et al. ${ }^{23}$ \\
\hline $\begin{array}{l}\text { Bone (Plesi- } \\
\text { ocetus sp.) }\end{array}$ & 1 & North Sea & 0.512034 & Modern & 23 & -11.8 & Tütken et al. ${ }^{23}$ \\
\hline Clay & 1 & North Sea & 0.512126 & Pleistocene & 10 & -10.0 & Tütken et al. ${ }^{23}$ \\
\hline
\end{tabular}

The Dutch residents lived in the area of Amsterdam ( $n=22)$ and Rotterdam $(n=13)$ at the time of formation of their M3's. Amsterdam and Rotterdam are situated in locations that were formed by different parts of the greater Rhine river system, potentially leading to local $\mathrm{Nd}$ isotope variations (as demonstrated for $\mathrm{Sr}$ by Kootker et al. $\left.{ }^{49}\right)$. Individuals residing in Warmenhuizen $(n=1)$, Alkmaar $(n=1)$, Purmerend $(n=1)$ and Zaandam $(n=2)$ were included in the Amsterdam population as these cities are located in similar geological substrates. The individuals from Dordrecht $(n=2)$ were similarly combined with those from Rotterdam. Analysis was performed on the hard mineralized outer surface of the teeth, the enamel. The enamel of third molars is formed between the age of 8-16 years ${ }^{8}$ and isotopic results are representative of the origin of the individual during this time period. This study was approved by the Medical Ethics Review Committee of the VU University Medical Center. Anonymous questionnaires were filled in by donors, covering general background information, including their geographical origin, diet, health, smoking and exercise habits. Teeth from Amsterdam were previously analysed for $\mathrm{Sr}, \mathrm{O}$, and $\mathrm{Pb} .^{1}$ In this study the enamel was analysed for both $\mathrm{Nd}$ concentration and composition.

\section{Methodology}

\subsection{Sample preparation}

All teeth were sampled, chemically processed and analysed at the Faculty of Science, Vrije Universiteit Amsterdam. The teeth were leached overnight in $30 \% \mathrm{H}_{2} \mathrm{O}_{2}$ (Sigma-Aldrich Company Ltd) followed by a rinsing step in ultrapure water (Milli-Q) and air dried on a hotplate at $50{ }^{\circ} \mathrm{C}$ prior to sampling. The enam- 
el was sampled using a dental micro-drill fitted with a diamond-tipped rotary burr and blade (Minilor Perceuse). The burr and blade were cleaned between sampling with $3 \mathrm{~N} \mathrm{HNO}_{3}$ in an ultrasonic bath for 3 minutes to remove any residual particles and then rinsed with Milli-Q and dried. The innermost layer of enamel (at the enamel-dentine junction) was mechanically removed to ensure optimal enamel-dentine separation. Sample weight ranged from 273-1233 mg, average $515 \mathrm{mg}$. If a M3 pair was available from a single donor, the enamel from both teeth was combined to increase available sample size.

\subsection{Chemical separation}

Sample dissolution and $\mathrm{Nd}$ chromatographic separation was performed in a class 100 clean laboratory. All PFA laboratory equipment was sub-boiled in pro-analysis quality $7 \mathrm{~N} \mathrm{HNO}_{3}$ and $6 \mathrm{~N} \mathrm{HCl}$ for two hours each, followed by two leaching steps at $125^{\circ} \mathrm{C}$ with 1) double distilled $6.5 \mathrm{~N} \mathrm{HCl}$ (>5 days) and 2) $7 \mathrm{~N}$ $\mathrm{HNO}_{3} / 12 \mathrm{~N} \mathrm{HF}$ (>2 days).

Thorough removal of organic matter was essential due to large sample size required to obtain enough $\mathrm{Nd}$ for analysis. The enamel was dissolved in 3-6 mL 6.5 N HCl, dried, nitrated, and re-dissolved in 3-6 $\mathrm{mL}$

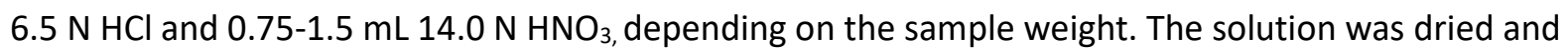
nitrated before it was dissolved in $10 \mathrm{~mL} 2.0 \mathrm{~N} \mathrm{HNO}_{3}$ for the extraction of the LREE with TRU-resin using an adapted protocol described in section 4.2.2. After LREE extraction $\mathrm{Nd}$ was separated from the other LREE using Ln-resin (Eichrom Technologies) following standard procedure. ${ }^{50}$

\subsubsection{Neodymium isotope concentration}

In order to determine the range of $\mathrm{Nd}$ concentrations in human teeth, isotope dilution using a ${ }^{150} \mathrm{Nd}$ enriched spike $\left({ }^{150} \mathrm{Nd} /{ }^{144} \mathrm{Nd}=142.93\right)$ was performed on a $10 \%$ aliquot of a subset of the samples $(\mathrm{n}=$ 23). Sample aliquots were chromatographically separated following standard TRU-resin column extraction (Eichrom, $150 \mu \mathrm{L}$ resin, 100-150 $\mu \mathrm{m}$ ) and standard Ln-resin columns (Eichrom, $740 \mu \mathrm{L}$, 50-100 $\mu \mathrm{m}) .{ }^{50}$

\subsubsection{Neodymium isotope composition}

The calcium-rich enamel samples of $>250 \mathrm{mg}$ required the development of a new $\mathrm{Nd}$ separation protocol, to prevent overloading of conventional chromatographic columns and to achieve removal of $\mathrm{Ca}$ in the purified $\mathrm{Nd}$ fraction, while minimizing the procedural blank because of low $\mathrm{Nd}$ concentrations in the samples $(<0.1 \mathrm{ppm})$. Excessive $\mathrm{Ca}$ in the tooth enamel samples initially caused poor $\mathrm{Nd}$ column yields and low ionisation efficiency in the mass spectrometer. Removal of Ca was accomplished with a novel TRU-resin protocol using a modified column made from Pasteur pipettes (Fig. 2). The TRU-resin volume used depended on the sample size: $0.75 \mathrm{~mL}$ resin for samples up to $550 \mathrm{mg}$ and $1.3 \mathrm{~mL}$ resin for samples $>550 \mathrm{mg}$. 
1. REE separation

0.75 or $1.3 \mathrm{~mL}$ TRU-resin

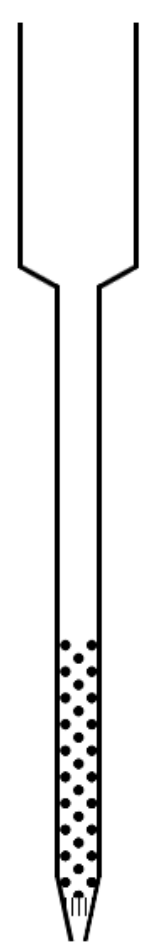

\author{
Cleaning \\ $6 \mathrm{~mL} 2 \mathrm{~N} \mathrm{HF}$ \\ $6 \mathrm{~mL}$ Milli-Q \\ $6 \mathrm{~mL} 2 \mathrm{~N} \mathrm{HNO}_{3}$ \\ $6 \mathrm{~mL}$ Milli-Q \\ Precondition \\ $6 \mathrm{~mL} 2 \mathrm{~N} \mathrm{HNO}_{3}$ \\ Prefaction (25 CV) \\ 19 or $33 \mathrm{~mL} 2 \mathrm{~N} \mathrm{HNO}_{3}$
}

8 or $14 \mathrm{~mL}$ Milli-Q

Precondition

$6 \mathrm{~mL} 2 \mathrm{~N} \mathrm{HNO}_{3}$

Prefraction
Sample load: $10 \mathrm{~mL} 2 \mathrm{~N} \mathrm{HNO}_{3}$

Wash: 9 or $23 \mathrm{~mL} 2 \mathrm{~N} \mathrm{HNO}_{3}$

REE extraction (10 CV)

Sample load: 9.6 or $16.8 \mathrm{~mL} 2 \mathrm{~N} \mathrm{HNO}_{3}$

Wash: 9.4 or $16.2 \mathrm{~mL} 2 \mathrm{~N} \mathrm{HNO}_{3}$ Second REE extraction

8 or $14 \mathrm{~mL}$ Milli-Q
2. Nd separation

$0.74 \mathrm{~mL}$ Ln-resin

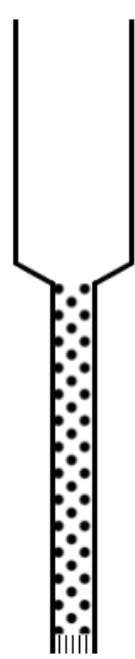

Cleaning

$4 \mathrm{~mL} 6 \mathrm{~N} \mathrm{HNO}_{3}$

$4 \mathrm{~mL} 2 \mathrm{~N} \mathrm{HF}$

$4 \mathrm{~mL}$ Milli-Q

$4 \mathrm{~mL} 6-7 \mathrm{~N} \mathrm{HCl}$

$1 \mathrm{~mL} 0.165 \mathrm{~N} \mathrm{HCl}$

Storage overnight

Cleaning

$2 \mathrm{~mL} 6-7 \mathrm{~N} \mathrm{HCl}$

$2 \mathrm{~mL}$ Milli-Q

Precondition

$2 \mathrm{~mL} 0.165 \mathrm{~N} \mathrm{HCl}$

Prefraction

9-11 mL 0.165 N HCl

Sample load:

$1-2 \mathrm{~mL} 0.165 \mathrm{~N} \mathrm{HCl}$

Wash:

7-10 mL $0.165 \mathrm{~N} \mathrm{HCl}$

Nd extraction:

$4 \mathrm{~mL} 0.3 \mathrm{~N} \mathrm{HCl}$

Fig. 2 Schematic overview of the chemical separation method for $\mathrm{Nd}$ separation for Ca-rich samples. REE from samples and standards were first extracted using TRU-resin employing Pasteur pipettes (35 $\mu \mathrm{m}$ polyethelene frit). Subsequently the Nd was extracted using Ln-resin. CV stands for column volume, which equals the volume of resin used.

Column extraction followed the procedure described in Fig. 2. Samples were ultrasonicated for 30 minutes and centrifuged for 4 minutes at $4000 \mathrm{rpm}$ before loaded onto the column. After the first extraction in $8 \mathrm{~mL}$ (samples $<550 \mathrm{mg}$ ) or $14 \mathrm{~mL}$ (samples $>550 \mathrm{mg}$ ) Milli-Q, the REE fraction was collected and reloaded onto the column for further purification. The REE fraction was then dried overnight on a hotplate at $120^{\circ} \mathrm{C}$, followed by dissolution in $2 \mathrm{~mL} 0.165 \mathrm{~N} \mathrm{HCl}$ for $\mathrm{Nd}$ separation using Ln columns. Standard Ln-resin procedure ${ }^{50}$ was followed after LREE extraction, as the tooth enamel matrix is removed during TRU-resin purification. After $\mathrm{Nd}$ extraction, samples were dried down and nitrated with ten drops of concentrated $\mathrm{HNO}_{3}$, fluxed for two hours at $120^{\circ} \mathrm{C}$, before a final drying step prior to TIMS analysis.

The efficiency of the new column extraction protocol was validated using both an internal synthetic tooth enamel $\mathrm{Nd}$ standard (see section 4.3) and a standard Nd solution (Alfa Aesar, ICP standard code: 9301120). The $\mathrm{Nd}$ standard ( $3 \mathrm{ppb}$ ), to which $1000 \mathrm{mg}$ of $\mathrm{Ca}_{3}\left(\mathrm{PO}_{4}\right)_{2}$ was added to mimic the enamel matrix, was analysed using a quadrapole Thermo X-Series II inductively coupled plasma mass spectrometer (ICP-MS) to determine the extraction efficiency. Yields approaching $90 \%$ were achieved on 
samples (1 g) using $1.3 \mathrm{~mL}$ TRU-resin, similar to yields for standard TRU-resin procedure.

\subsection{Tooth standard}

A secondary standard was fabricated to validate the modified TRU-resin protocol and overall analytical procedures. Because the $\mathrm{Nd}$ concentration of teeth is low it was not viable to create a tooth standard from human teeth. The synthetic tooth standard (TSTD) consists of $400 \mathrm{~g} \mathrm{CaHPO}_{4}$ (Alfa Aesar) dissolved

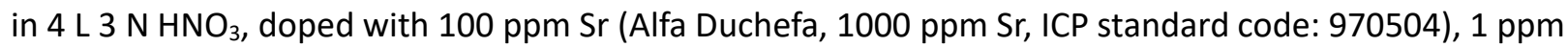
$\mathrm{Pb}$ (CPI International, 1000 ppm Pb, ICP standard code: P/N 4400-1000281), and 4 ppb Nd (Alfa Aesar, ICP standard code: 9301120). Different sizes of TSTD aliquots were processed on both the standard 0.3 TRU-resin columns (1.25-3 mL TSTD, 0.5-1.2 ng Nd, 125-300 mg CaHPO 4 ) and on the new 0.75 and 1.3 $\mathrm{mL}$ TRU-resin columns (10 mL, $4 \mathrm{ng} \mathrm{Nd}, 1000 \mathrm{mg} \mathrm{CaHPO}$ ).

\subsection{TIMS}

Neodymium analyses were performed on a Thermo Scientific Triton Plus TIMS. Standards and samples were loaded on out-gassed Re filaments in 1-2 $\mu \mathrm{L} 10 \% \mathrm{HNO}_{3}$ with $1 \mu \mathrm{L} \mathrm{H}_{3} \mathrm{PO}_{4}$ (see Koornneef et al. ${ }^{51}$ for details). Analyses were performed using $10^{13} \Omega$ resistors fitted to the amplifier system (see Koornneef et al. ${ }^{52}$ for analysis techniques) and $10^{11} \Omega$ resistors if enough sample was available. Use of these $10^{13} \Omega$ resistors results in a 100 fold higher output voltage compared to default $10^{11} \Omega$ resistors, while the electronical noise level only increases by a factor of 10, improving the signal to noise ratio by a factor of 10 . The $10^{13} \Omega$ resistors therefore produce more precise data on small ion beams $s^{50}$ and avoid the drawbacks of the $\mathrm{NdO}^{+}$technique (variation in oxygen isotope composition and multiple isobaric interferences). ${ }^{51,53}$

For $\mathrm{Nd}^{+}$analyses four $10^{13} \Omega$ amplifiers were connected to masses ${ }^{143} \mathrm{Nd}$ to ${ }^{146} \mathrm{Nd}$, with ${ }^{146} \mathrm{Nd}$ in the centre cup. Masses ${ }^{142} \mathrm{Nd},{ }^{147} \mathrm{Nd}$ and ${ }^{148} \mathrm{Nd}$ were measured using $10^{11} \Omega$ amplifiers. To optimise measurement time, amplifier baselines were measured during sample heating (11 minutes) and subtracted online from the raw intensity values. Instrumental mass fractionation was corrected using the exponential law and a ${ }^{146} \mathrm{Nd} /{ }^{144} \mathrm{Nd}$ value of 0.7219 . A gain correction was performed by measuring the La Jolla reference standard $(0.511841 \pm 0.000002)^{51}$ overnight and using these values to calculate the gains for the $10^{13} \Omega$ amplifiers. During the La Jolla measurement the four $10^{13} \Omega$ resistors were connected to cups $L 3\left(\mathrm{Nd}^{143}\right), \mathrm{L} 1$ $\left(\mathrm{Nd}^{145}\right), \mathrm{H} 2\left(\mathrm{Nd}^{148}\right)$ and $\mathrm{H} 4\left(\mathrm{Nd}^{150}\right)$. The averaged results for ${ }^{143} \mathrm{Nd} /{ }^{144} \mathrm{Nd},{ }^{145} \mathrm{Nd} /{ }^{144} \mathrm{Nd},{ }^{148} \mathrm{Nd} /{ }^{144} \mathrm{Nd}$, ${ }^{150} \mathrm{Nd} /{ }^{144} \mathrm{Nd}$ from at least 7 separate La Jolla measurements were used to calculate the gain values for the $10^{13} \Omega$ amplifiers using the following formula: gain value $=0.01 *$ (true value $L a$ Jolla/measured value $L a$ Jolla). Beam intensities on $10^{13} \Omega$ resistors were always kept below $0.03 \mathrm{~V}$ ( $30 \mathrm{mV}$ if measured on a $10^{11}$ $\Omega$ amplifier) to avoid the effect of potential non-linearity of the amplifiers. A minimum of 70 scans was collected for each analysis on $10^{13} \Omega$ amplifiers, and 60 scans for $10^{11} \Omega$ amplifiers. Larger standards and samples were stopped after 300-400 cycles using $10^{13} \Omega$ resistors and re-analysed using $10^{11} \Omega$ to ensure optimal precision and accuracy. Standards (JNdi-1, CIGO (in-house standard, see Koornneef et al. ${ }^{51}$ ) and TSTD) were measured to check for accuracy and reproducibility and for normalisation purposes. Total procedural blanks yielded $1.1 \pm 1.4 \mathrm{pg}$ for $\mathrm{Nd}(\mathrm{n}=48)\left({ }^{150} \mathrm{Nd} /{ }^{144} \mathrm{Nd}=142.93\right)$. Previous research in our lab demonstrated that samples as small as $30 \mathrm{pg} \mathrm{Nd}$ can be analysed without suffering from procedural blanks. ${ }^{50}$ 


\section{Results}

\subsection{Validation}

Accuracy of analysis techniques using $10^{13} \Omega$ resistors was assessed using large ( $200 \mathrm{ng}$ ) and small (100 $\mathrm{pg}$ ) aliquots of standards. For large aliquots the $10^{13} \Omega \mathrm{CIGO}\left({ }^{143} \mathrm{Nd} /{ }^{144} \mathrm{Nd}=0.511348 \pm 0.000078\right.$ (2SD), $\mathrm{n}$ $=61)$ and JNdi-1 results $(0.512110 \pm 0.000092(2 S D), n=21)$ are in excellent agreement with the longterm average of CIGO $\left({ }^{143} \mathrm{Nd} /{ }^{144} \mathrm{Nd}=0.511328 \pm 0.000009(2 \mathrm{SD}), \mathrm{n}=39\right)$ and JNdi-1 $\left({ }^{143} \mathrm{Nd} /{ }^{144} \mathrm{Nd}=\right.$ $0.512096 \pm 0.000009$ (2SD), $n=19$ ) in this laboratory determined on default $10^{11} \Omega$ amplifiers (Table 3 ).

Table 3 Results of in-house standard (CIGO $250 \mathrm{ng}$, CIGO $0.1 \mathrm{ng}$ ), international standard (JNdi-1) and synthetic tooth standard (TSTD) for $10^{13}$ and $10^{11} \Omega$ amplifiers when possible.

\begin{tabular}{rrrrrr} 
Standard & Quantity & Amplifier & ${ }^{143} \mathbf{N d} /{ }^{144} \mathbf{N d}$ & 2SE & \multicolumn{2}{c}{$\mathbf{n}$} \\
CIGO & $250 \mathrm{ng}$ & $10^{13}$ & 0.511348 & 0.000078 & 61 \\
& & $10^{11}$ & 0.511328 & 0.000009 & 47 \\
CIGO & $100 \mathrm{pg}$ & $10^{13}$ & 0.511346 & 0.000070 & 29 \\
JNdi-1 & $200 \mathrm{ng}$ & $10^{13}$ & 0.512107 & 0.000092 & 21 \\
& & $10^{11}$ & 0.512096 & 0.000009 & 19 \\
TSTD & $0.5-4.0 \mathrm{ng}$ & $10^{13}$ & 0.512129 & 0.000030 & 74 \\
& $1-4 \mathrm{ng}$ & $10^{11}$ & 0.512126 & 0.000061 & 43
\end{tabular}

The accuracy and reproducibility of small samples was assessed using $100 \mathrm{pg}$ aliquots of the CIGO standard and analysis of the TSTD on both $10^{13}$ and $10^{11} \Omega$ amplifiers. The $10^{13} \Omega$ results for the $100 \mathrm{pg}$ CIGO standards are in agreement with the $250 \mathrm{ng} \mathrm{CIGO}$ standards measured using $10^{13} \Omega$ amplifiers (Table 3). The $100 \mathrm{pg}$ CIGO standards did not contain enough $\mathrm{Nd}$ to be reanalysed using $10^{11} \Omega$ resistors. To check for overall reproducibility of Ca-rich samples, TSTDs were analysed using the $10^{13} \mathrm{amplifiers}$ and $10^{11}$ amplifiers if enough $\mathrm{Nd}(>1 \mathrm{ng} \mathrm{Nd})$ was present. TSTDs ( $n=43,>1 \mathrm{ng} \mathrm{Nd}$ ) and larger samples $(n=5)$ were measured twice, using the same filament, first on $10^{13} \Omega$ resisters and subsequently on $10^{11} \Omega$ resistors. The results of the TSTD and samples on $10^{13} \Omega$ and $10^{11} \Omega$ are in agreement (Table 3 and 4, Fig. $3)$. The TSTD $10^{13} \Omega$ analytical reproducibility $( \pm 0.000071)$ in $\mathrm{Nd}$ isotope composition is an indication of the reproducibility in $\mathrm{Nd}$ composition present in the samples undergoing the entire laboratory procedure, as the TSTD has a similar matrix and Nd concentration (4 ppb) as enamel (average $3.7 \mathrm{ppb}$ ). 


\section{$10^{11}$ and $10^{13}$}

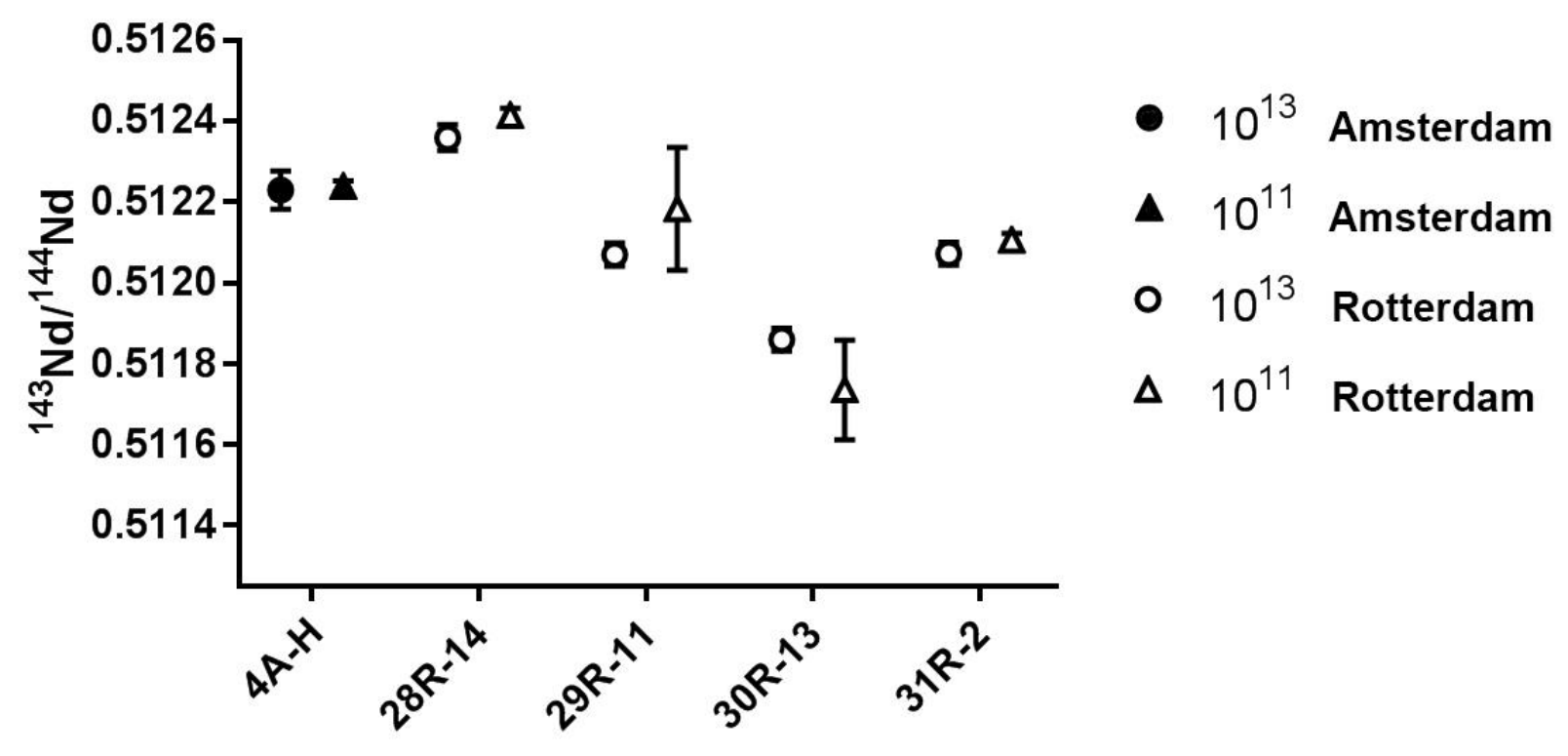

Individuals

Fig. $3{ }^{143} \mathrm{Nd} /{ }^{144} \mathrm{Nd}$ results for enamel samples using both $10^{13}$ and $10^{11} \Omega$ resistors $(n=4)$.

Table 4 Validation of measurement by repeat analyses $(n=5)$ on samples using both $10^{13} \Omega$ and $10^{11} \Omega$ resistors.

\begin{tabular}{|c|c|c|c|c|c|c|}
\hline \multirow{2}{*}{$\begin{array}{l}\text { Sample } \\
\text { ID }\end{array}$} & \multicolumn{3}{|l|}{$10^{13}$} & \multicolumn{3}{|l|}{$10^{11}$} \\
\hline & ${ }^{143} \mathrm{Nd} /{ }^{144} \mathrm{Nd}$ & 2SE & Scans & ${ }^{143} \mathrm{Nd} /{ }^{144} \mathrm{Nd}$ & 2SE & Scans \\
\hline $4 \mathrm{~A}-\mathrm{H}$ & 0.512229 & 0.000047 & 369 & 0.512238 & 0.000014 & 64 \\
\hline $28 \mathrm{R}-14$ & 0.512388 & 0.000032 & 332 & 0.512414 & 0.000018 & 263 \\
\hline $29 R-11$ & 0.512080 & 0.000029 & 305 & 0.512183 & 0.000152 & 62 \\
\hline 30R-13 & 0.511869 & 0.000028 & 281 & 0.511735 & 0.000123 & 63 \\
\hline $31 R-2$ & 0.512048 & 0.000028 & 284 & 0.512106 & 0.000016 & 104 \\
\hline
\end{tabular}

\section{$5.2 \mathrm{Nd}$ elemental concentration}

The enamel of 23 Dutch individuals was analysed for $\mathrm{Nd}$ concentration. Concentrations ranged from 0.1 ppb to $21.0 \mathrm{ppb}$ (Fig. 4), with a median of $1.2 \mathrm{ppb}$. All but two values of 19.8 and $21.0 \mathrm{ppb}$ fell in the range 0.1 to $7.0 \mathrm{ppb}$. Based on the concentration data, samples containing $>100 \mathrm{pg}$ were successfully measured for $\mathrm{Nd}$ isotope composition. 


\section{Nd Concentration}

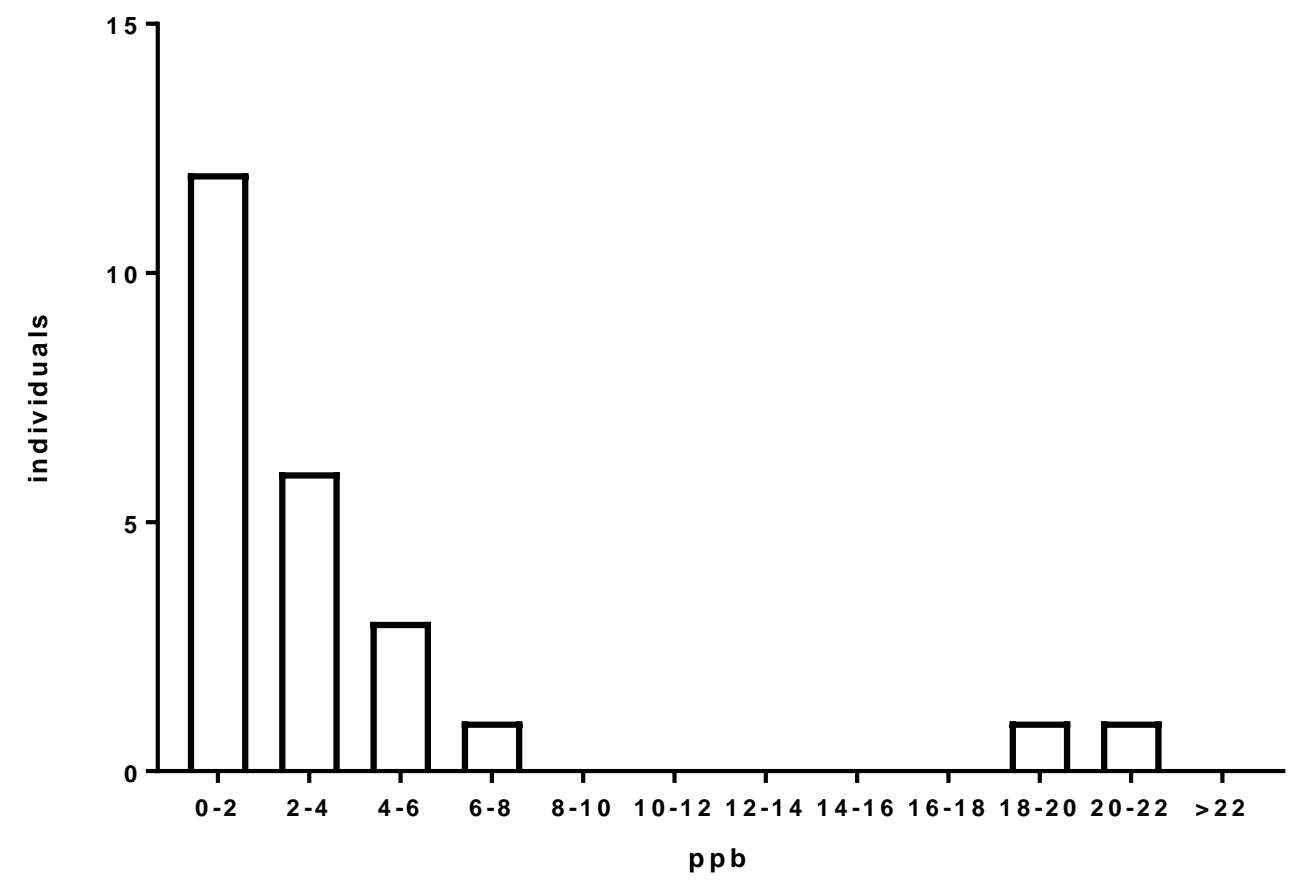

Fig. $4 \mathrm{Nd}$ concentrations for enamel samples from 20 Dutch inhabitants $(n=23)$.

\section{$5.3 \mathrm{Nd}$ isotope composition}

Results for the enamel of the third molars are presented in Table 5 and Fig. 5 . A total of 20 samples were analysed successfully (>70 scans) for their $\mathrm{Nd}$ isotope composition (out of a total of $n=32$ ). On average samples ran for 223 scans using $10^{13}$ resistors. The ${ }^{143} \mathrm{Nd} /{ }^{144} \mathrm{Nd}$ isotope composition from individuals from Amsterdam ranged from 0.51204-0.51259 and values from Rotterdam ranged between 0.511870.51239 . The ${ }^{143} \mathrm{Nd} /{ }^{144} \mathrm{Nd}$ isotope composition of enamel between Amsterdam and Rotterdam samples was significantly different ( $P$ value $=0.02$, unpaired $T$-test) . 
Table 5 Third molars $(n=35)$ analysed for $\mathrm{Nd}$ concentration and composition for 32 Dutch individuals. Third molars from Amsterdam $(n=12)$ and Rotterdam $(n=8)$ and surrounding areas were analysed for $\mathrm{Nd}$ composition using $10^{13}$ resistors. ${ }^{*}=$ two third molars used.

\begin{tabular}{|c|c|c|c|c|c|c|c|}
\hline Sample & Location & $\begin{array}{l}\text { Sample size } \\
\text { (mg) }\end{array}$ & $\begin{array}{l}\text { Nd } \\
\text { content } \\
\text { (ppb) }\end{array}$ & ${ }^{143} \mathrm{Nd} /{ }^{144} \mathrm{Nd}$ & 2SE & Scans & $\varepsilon N d$ \\
\hline $1 A-22$ & Amsterdam & 530 & & 0.512044 & 0.000044 & 377 & -11.6 \\
\hline $2 A-20$ & Warmenhuizen & 511 & 1.3 & 0.512091 & 0.000037 & 204 & -10.7 \\
\hline $3 A-24$ & Amsterdam & 529 & 2.3 & 0.512193 & 0.000029 & 373 & -8.7 \\
\hline $4 \mathrm{~A}-\mathrm{H}$ & Purmerend & 320 & 19.8 & 0.512229 & 0.000047 & 369 & -7.7 \\
\hline $5 A-25$ & Amsterdam & 350 & 0.7 & 0.512056 & 0.000091 & 357 & -11.4 \\
\hline $6 A-10$ & Amsterdam & 276 & 3.1 & 0.512175 & 0.000032 & 80 & -9.0 \\
\hline $7 A-13$ & Amsterdam & 279 & 0.4 & 0.512098 & 0.000059 & 307 & -10.5 \\
\hline $8 A-27$ & Alkmaar & 273 & & 0.512185 & 0.000188 & 141 & -8.8 \\
\hline $9 A-28$ & Amsterdam & 513 & & 0.512380 & 0.000119 & 158 & -5.0 \\
\hline 10A-18 & Amsterdam & 418 & & 0.512288 & 0.000119 & 161 & -6.8 \\
\hline $11 \mathrm{~A}-15$ & Amsterdam & 431 & & 0.512589 & 0.000080 & 200 & -1.0 \\
\hline $12 \mathrm{~A}-9$ & Amsterdam & 299 & 1.1 & 0.512330 & 0.000124 & 150 & -6.0 \\
\hline $13 A-6$ & Amsterdam & 27 & 1.2 & & & & \\
\hline $14 A-8$ & Amsterdam & 16 & 0.9 & & & & \\
\hline $15 \mathrm{~A}-12$ & Amsterdam & 22 & 1.6 & & & & \\
\hline $16 \mathrm{~A}-23$ & Amsterdam & 24 & 0.2 & & & & \\
\hline $17 \mathrm{~A}-32$ & Amsterdam & 22 & 3.0 & & & & \\
\hline $18 \mathrm{~A}-41$ & Amsterdam & 23 & 3.4 & & & & \\
\hline 19A-42 & Amsterdam & 22 & 0.7 & & & & \\
\hline $20 \mathrm{~A}-\mathrm{K}$ & Purmerend & 25 & 7.0 & & & & \\
\hline 21A-Sa & Zaandam & 22 & 4.4 & & & & \\
\hline $22 \mathrm{~A}-\mathrm{Sb}$ & Zaandam & 21 & 0.2 & & & & \\
\hline $23 R-37$ & Rotterdam & 27 & 1.1 & & & & \\
\hline $24 R-1 a$ & Dordrecht & 69 & 5.7 & & & & \\
\hline $25 R-1 b$ & Dordrecht & 29 & 3.0 & & & & \\
\hline $26 \mathrm{R}-4$ & Dordrecht & 52 & 2.5 & & & & \\
\hline $27 R-14 b$ & Dordrecht & 51 & 0.6 & & & & \\
\hline 28R-14a & Dordrecht & 429 & 21.0 & 0.512388 & 0.000032 & 332 & -4.9 \\
\hline 29R-11 & Rotterdam & $1233^{*}$ & & 0.512080 & 0.000029 & 305 & -10.9 \\
\hline 30R-13 & Rotterdam & $870^{*}$ & & 0.511869 & 0.000028 & 281 & -15.0 \\
\hline $31 \mathrm{R}-2$ & Rotterdam & 482 & & 0.512048 & 0.000028 & 284 & -11.5 \\
\hline $32 R-3$ & Rotterdam & $746^{*}$ & & 0.511945 & 0.000048 & 174 & -13.5 \\
\hline $33 R-9$ & Rotterdam & 589 & & 0.511972 & 0.000100 & 172 & -13.0 \\
\hline $34 R-5$ & Dordrecht & 582 & & 0.511987 & 0.000105 & 108 & -12.7 \\
\hline $35 R-9$ & Rotterdam & 636 & & 0.512020 & 0.000166 & 72 & -12.1 \\
\hline
\end{tabular}




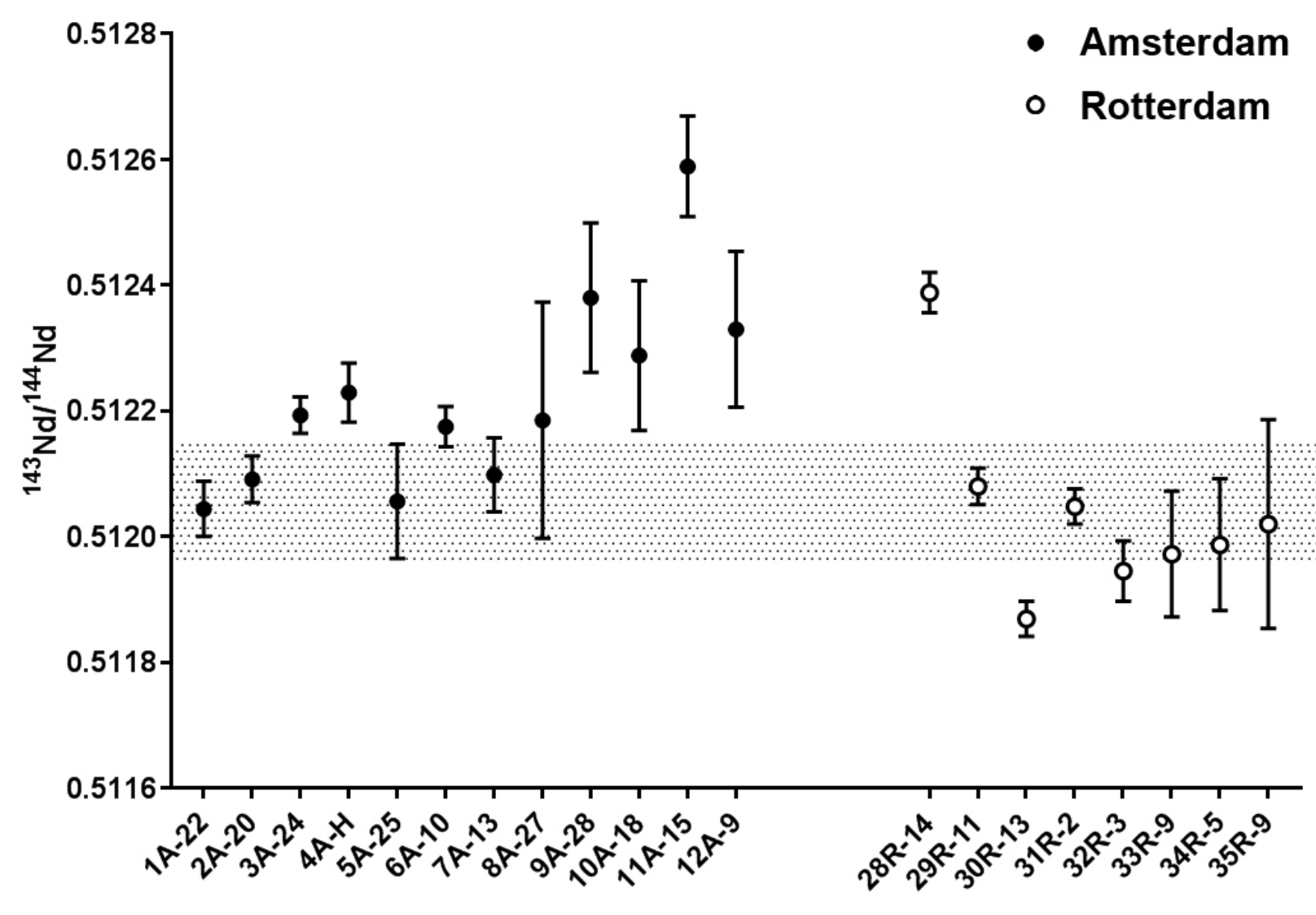

Fig. 5 Third molars analysed using $10^{13} \Omega$ resistors from Dutch inhabitants of Amsterdam $(n=12)$ and Rotterdam $(n=8)$ and surrounding areas. The highlighted area $\left({ }^{143} \mathrm{Nd} /{ }^{144} \mathrm{Nd}=0.511983-0.512166\right)$ represents the Dutch range based on Rhine sediments analyses (see section 3 ).

\section{Discussion}

\subsection{Analytical validation}

Internal standard (CIGO and TSTD) results demonstrate that $100 \mathrm{pg}$ (CIGO) and $500 \mathrm{pg}$ (TSTD) Nd standards yield accurate and reproducible $\mathrm{Nd}$ isotope data (Table 3). The accuracy of measurements using $10^{13} \Omega$ amplifiers is confirmed by successful repeat analysis of TSTDs $(n=43)$ and enamel samples $(n=5)$ using both the $10^{11}$ and $10^{13} \Omega$ amplifiers (Fig. 3, Table 4). Neodymium analysis using $10^{13} \Omega$ resistors has been validated by previous research. ${ }^{50,54,55}$ This study confirms the results of previous studies on melt inclusions ${ }^{50}$ and diamonds, ${ }^{54}$ which show that the $10^{13} \Omega$ resistors are beneficial to use for analyses of sub-nanogram sample sizes compared to $10^{11} \Omega$ resistors, as the $10^{11} \Omega$ amplifiers require $\sim 10 \mathrm{ng} \mathrm{Nd}$ for successful analyses. ${ }^{23}$ The successful analysis of small $\mathrm{Nd}$ samples $(0.5-4.0 \mathrm{ng})$ in human enamel using $10^{13} \Omega$ resistors demonstrates the potential for the study of $\mathrm{Nd}$ isotope composition in human tissues. Furthermore, TIMS analysis employing $10^{13} \Omega$ resistors opens up new possibilities for studies with access to limited sample material ${ }^{23}$ and facilitates the analysis of $\mathrm{Sr}$ and $\mathrm{Pb}$ isotopes in 
human tissues previously considered too precious for destructive analysis, ${ }^{56}$ as the sample size required for analysis is reduced.

\subsection{Nd elemental concentration}

$\mathrm{Nd}$ concentrations in human tooth enamel (1.2 ppb median with two outliers c. 20 ppb, Fig.4, Table 5) are consistent with the limited published data that concluded that $\mathrm{Nd}$ concentrations in human teeth are below $0.1 \mathrm{ppm} .{ }^{22}$ The results of this study show that $\mathrm{Nd}$ concentration in enamel is generally lower than in other human tissues such as hair, nails, bone, blood, and soft tissues (see Table 2), although low values have also been reported for hair, ${ }^{36}$ urine and blood. ${ }^{35}$ The mean Nd concentration in rib bone (11 $\mathrm{ppb})^{39}$ is more than three times higher than in enamel. Variation in $\mathrm{Nd}$ concentrations in human tissues may be the result of different formation times of the tissues. The rib bone analysed grew in adulthood, while third molar enamel is formed during childhood and early adolescence ( $8-16$ years). ${ }^{8}$ Little is known about the variation of $\mathrm{Nd}$ concentration in tissues between adults and children, as most studies focus on adult individuals. One study published Nd concentrations from children's hair ${ }^{36}$ that were almost 100 times lower than adult values, ${ }^{34,37,38}$ but these values may be affected by the use of EDTA in the cleaning procedure ${ }^{36}$ possibly leaching Nd out of the children's hair. In the present study, the samples were only oxidised in $30 \% \mathrm{H}_{2} \mathrm{O}_{2}$. The cleaning procedures used in the lab are therefore not the cause of the low $\mathrm{Nd}$ concentrations present in tooth enamel.

Low $\mathrm{Nd}$ concentrations in human tissues can partly be attributed to the generally low $\mathrm{Nd}$ concentrations in the food chain: plants and rivers have lower $\mathrm{Nd}$ concentrations (ppb range) than the underlying geology. ${ }^{57-59}$ Although post-mortem absorption of $\mathrm{Nd}$ in fossil faunal remains has been investigated, ${ }^{23,24,60}$ little is known about the in vivo absorption of $\mathrm{Nd}$ as it is difficult to analyse in human biological systems. Low concentrations of $\mathrm{Nd}$ in human enamel may be caused by preferential exclusion of $\mathrm{Nd}$, as the trivalent ion $\left(\mathrm{Nd}^{3+}\right)$ is less likely to substitute for $\mathrm{Ca}^{2+}$ in the hydroxyapatite crystal lattice, compared to for example $\mathrm{Sr}^{2+}$. The moderately toxic nature of $\mathrm{Nd}$ may also explain its excretion by the liver, with poor intestinal absorption of REEs shown in animal experiments. ${ }^{61,62}$ The combination of low bioavailable Nd to humans and its excretion by the liver is likely causing the generally low $\mathrm{Nd}$ concentrations in human tissues. Increased $\mathrm{Nd}$ concentrations in humans seem to be caused by absorption of $\mathrm{Nd}$ through the respiratory system. ${ }^{33}$

The high Nd concentration analysed in the enamel of two individuals was atypical (19.8 and $21.0 \mathrm{ppb}$ ) and could not be explained based on their background information. The elevated $\mathrm{Nd}$ concentration in tissues from individuals that live in mining areas or have mining occupations ${ }^{34}$ suggests that $\mathrm{Nd}$ uptake through air or dermal contact may overwrite the geological signal, similar to the $\mathrm{Pb}$ system. ${ }^{14}$ However, concentrations reported in this study do not reach the elevated values reported for mining areas. ${ }^{34,35}$ Anthropogenic input from industrial products cannot be fully excluded however, as even small contributions would affect the low $\mathrm{Nd}$ concentrations in human enamel. Potential sources of $\mathrm{Nd}$ pollution include oil and petroleum refineries, fossil fuel combustion, production of high performance magnets, waste incineration and metallurgic processes which can release REE emissions to air, soil and water. ${ }^{57}$ Industrial REE dust emission is usually low, however, and has decreased in the last decades in Europe due to improved emission control. ${ }^{57}$ The two individuals with increased $\mathrm{Nd}$ concentrations (4A-H and 28R-14) were furthermore not resident near industrial sites. Instead, individuals from Rotterdam 
that are situated near industrial sites do not show elevated $\mathrm{Nd}$ concentrations in their enamel. This makes industrial $\mathrm{Nd}$ emission an unlikely candidate for the increased $\mathrm{Nd}$ concentrations in the individuals from the Netherlands, although local exposure cannot be completely excluded. Based on current studies it thus remains difficult to explain why certain individuals have a marked increased $\mathrm{Nd}$ concentration present in their enamel. Large variation in $\mathrm{Nd}$ content with apparent outliers in the sample population is also present in the majority of previous studies on human tissues (Table 1). It is therefore highly likely that some variation in $\mathrm{Nd}$ concentration in enamel $(0.1-21.0 \mathrm{ppb})$ is introduced by the human body.

\subsection{Nd isotope composition}

The ${ }^{143} \mathrm{Nd} /{ }^{144} \mathrm{Nd}$ ratios for $60 \%$ of the individuals analysed in this study are compatible with expectations for local Dutch geology, as defined by analyses of Rhine sediments $\left({ }^{143} \mathrm{Nd} /{ }^{144} \mathrm{Nd}=0.511983-0.512166\right)$. The Rotterdam individuals are in closer agreement to the local range, which is consistent with Rotterdam's geographical position near the Rhine. It is possible that the expected local range was too narrowly defined, as $40 \%$ of the samples in the study, particularly those from Amsterdam, had $\mathrm{Nd}$ isotope compositions outside the local range ( 7 are higher and 1 is lower, see Fig. 5). In order to build solid interpretations of an individual's origin based on isotopes, appropriate background sampling is required. The current local range is based on a very limited background sediment data-set $(n=18)$, potentially explaining the large proportion (40\%) of individuals falling outside of these values. Nevertheless, the high $\mathrm{Nd}$ composition values $\left({ }^{143} \mathrm{Nd} /{ }^{144} \mathrm{Nd}=>0.5122\right)$ seen here are incompatible with the geology of the Netherlands. Instead, elevated values are expected to be found in volcanic areas in Europe, such as Iceland and Italy. ${ }^{16}$ The variation and elevated $\mathrm{Nd}$ ratios found in this study suggests that either: (1) Nd in modern human diets in the Netherlands contains significant non-local contributions; (2) $\mathrm{Nd}$ is being fractionated significantly within the human body or in the food chain, for example with trophic level; or (3) there are local $\mathrm{Nd}$ sources other than geology (i.e. anthropogenic sources) contributing to human $\mathrm{Nd}$ composition in the Netherlands. It is unlikely that non-local food sources are completely overwriting the input of the local environment, as several studies have concluded that even with the globalisation of the food market isotopes $(\mathrm{H}, \mathrm{O}, \mathrm{C}, \mathrm{N}, \mathrm{S})$ can still be an indicator of geographical location of origin..$^{63,64}$ Due to its relatively high mass, neodymium is not expected to be an indicator of trophic level by fractionation, as is recorded for $\delta^{15} \mathrm{~N},{ }^{2} \mathrm{H},{ }^{66} \mathrm{Zn} /{ }^{64} \mathrm{Zn}$, and $\delta^{88} \mathrm{Sr} .{ }^{65-68}$ Interestingly, the highest $\mathrm{Nd}$ isotope composition measured in this study $\left({ }^{143} \mathrm{Nd} /{ }^{144} \mathrm{Nd}=0.512589 \pm 0.0008\right)$ belongs to individual 10A-15, who was the only study participant with a vegetarian diet. It remains possible that anthropogenic contributions to $\mathrm{Nd}$ are important, especially given the weak negative correlation between $\mathrm{Nd}$ concentration and $\mathrm{Nd}$ isotope value in the data reported here (Table $5, \mathrm{R}^{2}=0.3$ ). However, Tütken et al. ${ }^{23}$ found similar elevated ratios for the enamel of two mammoth teeth from the region, one from the North Sea and one from the Rhine River in Germany $\left({ }^{143} \mathrm{Nd} /{ }^{144} \mathrm{Nd}=0.51261\right.$ and 0.51229 respectively, Table 1) which cannot be explained by anthropogenic contributions or diagenesis. ${ }^{23}$

The statistical difference between Amsterdam and Rotterdam suggests that $\mathrm{Nd}$ analysis may provide information for provenance in the Netherlands that Sr analysis cannot (see discussion on Sr in Kootker et al. ${ }^{49}$ ). This conclusion would, however, be more plausible if the source of variation in Nd isotope composition in enamel is identified. The limited data available on $\mathrm{Nd}$ in human tissue and in the local environment makes it difficult to assess the reported variation. This study establishes that $\mathrm{Nd}$ isotope 
analysis of human tooth enamel is viable but that the application of $\mathrm{Nd}$ analysis needs to be further validated by analysis of a larger sample set, including individuals from a variety of geological contexts, as well as more extensive background sampling, before it can be applied in archaeological and forensic contexts.

\section{Conclusions}

This study successfully establishes that $\mathrm{Nd}$ isotope composition can be measured in human tooth enamel. Low $\mathrm{Nd}$ concentrations in enamel with a Ca-rich sample matrix require an adapted $\mathrm{Nd}$ chemical separation procedure to process large samples while keeping the blank as low as possible, and TIMS measurements employing new $10^{13} \Omega$ amplifiers to measure small ion beams at relatively high precision. The $\mathrm{Nd}$ concentration data confirms previous findings that the $\mathrm{Nd}$ concentration in human enamel is low (0.1 ppb to $21.0 \mathrm{ppb}$ ). High-precision $\mathrm{Nd}$ isotope analysis requires $>100 \mathrm{pg}$ of $\mathrm{Nd}$, an amount which can only be obtained when an individual has a relatively high $\mathrm{Nd}$ concentration $(>0.7 \mathrm{ppb})$ in the enamel, or if a larger sample size (>550 $\mathrm{mg}$ ) can be achieved by analysing multiple teeth of one individual. The required sample size for $\mathrm{Nd}$ analysis may limit the applicability of the technique. Neodymium isotope composition from Dutch inhabitants, though reliably measured, did not wholly correspond to expectations based on the limited available geological data. The lack of knowledge about Nd cycling in the environment and in human tissues meant that these discrepancies are difficult to interpret. In order to assess the potential of $\mathrm{Nd}$ isotopes for tracing the origins of human individuals, the variation in $\mathrm{Nd}$ composition in human tissue with residential geological context needs to be examined further.

\section{Conflicts of interest}

There are no conflicts to declare.

\section{Acknowledgements}

The research leading to these results has received funding from the European Research Council under the European Union's Seventh Framework Programme (FP7/2007-2013)/ERC grant agreement $n^{\circ} 319209$ and would not have been possible without the donations of teeth that was facilitated by the Vrije Universiteit's Medical Centre (VUMC) in Amsterdam, Ikazia Hospital and Erasmus Medical Centre in Rotterdam. The Nederlands Tandartsenblad is thanked for advertising our request to collect extracted teeth. The Medical Ethics Review Committee of the VU University Medical Center in Amsterdam is thanked for evaluating the sampling request (IDIS 2010/265). This paper was improved by the valuable feedback of Joshua Peterson and anonymous reviewers. 


\section{References}

1 L. Font, G. Van Der Peijl, C. Van Leuwen, I. Van Wetten and G. R. Davies, Sci. Justice, 2015, 55, 3442.

2 C. Lehn, A. Rossmann and M. Graw, Sci. Justice, 2015, 55, 72-88.

3 G. D. Kamenov and B. L. Gulson, Sci. Total Environ., 2014, 490, 861-870.

4 J. E. Laffoon, T. F. Sonnemann, T. Shafie, C. L. Hofman, U. Brandes and G. R. Davies, PLoS One, 2017, 12, 1-16.

5 L. M. Kootker, L. Mbeki, A. G. Morris, H. Kars and G. R. Davies, PLoS One, 2016, 11, 1-20.

6 H. Schroeder, K. A. Shuler and S. R. Chenery, Am. J. Phys. Anthropol., 2013, 150, 203-209.

7 M. A. Trickett, P. Budd, J. Montgomery and J. Evans, Appl. Geochemistry, 2003, 18, 653-658.

8 S. J. AlQahtani, M. P. Hector and H. M. Liversidge, Am. J. Phys. Anthropol., 2010, 142, 481-490.

9 G. J. Bowen, Annu. Rev. Earth Planet. Sci., 2010, 38, 161-87.

10 C. P. Bataille, J. E. Laffoon and G. J. Bowen, Ecosphere, 2012, 3, 1-24.

11 J. Evans, J. Montgomery, G. Wildman and N. Boulton, J. Geol. Soc. London., 2010, 167, 1-4.

12 A. T. Keller, L. A. Regan, C. C. Lundstrom and N. W. Bower, Forensic Sci. Int., 2016, 261, 83-92.

13 C. Reimann, M. Birke, A. Demetriades, P. Filzmoser and P. O'Connor, Chemistry of Europe's agricultural soils-Part A: Methodology and interpretation of the GEMAS data set., Bundesanstalt für Geowissenschaften und Rohstoffe (BGR), Hannover, 2014.

14 J. Montgomery, J. A. Evans, S. Chenery, V. Pashley and K. Killgrove, J. Rom. Archaeol., 2010, 78, 199-226.

R. A. Bentley, J. Archaeol. Method Theory, 2006, 13, 135-187.

A. Dickin, Radiogenic isotope geology, Cambridge University Press, Cambridge, 2005.

17 G. Dera, E. Pucéat, P. Pellenard, P. Neige, D. Delsate, M. M. Joachimski, L. Reisberg and M. Martinez, Earth Planet. Sci. Lett., 2009, 286, 198-207.

C. Jeandel, T. Arsouze, F. Lacan, P. Téchiné and J.-C. Dutay, Chem. Geol., 2007, 239, 156-164.

C. R. Pearce, M. T. Jones, E. H. Oelkers, C. Pradoux and C. Jeandel, Earth Planet. Sci. Lett., 2013, 369-370, 138-147.

21 I. Meyer, G. R. Davies, C. Vogt, H. Kuhlmann and J.-B. W. Stuut, Aeolian Res., 2013, 10, 111-123.

22 K. Pye, Geol. Soc. London, Spec. Publ., 2004, 232, 215-236.

23 T. Tütken, T. W. Vennemann and H. U. Pfretzschner, Geochim. Cosmochim. Acta, 2011, 75, 5951- 
5970.

M. J. Kohn, J. Morris and P. Olin, J. Archaeol. Sci., 2013, 40, 1689-1699.

C. Boschetti, J. Henderson and J. Evans, J. Archaeol. Sci. Reports, 2017, 11, 647-657.

D. Brems, J. Pauwels, A. Blomme, R. B. Scott and P. Degryse, STAR Sci. Technol. Archaeol. Res., 2016, 8923, 1-10.

27 F. Gallo, A. Silvestri, P. Degryse, M. Ganio, A. Longinelli and G. Molin, J. Archaeol. Sci., 2015, 62, 55-65.

K. Tachikawa, T. Arsouze, G. Bayon, A. Bory, C. Colin, J. C. Dutay, N. Frank, X. Giraud, A. T. Gourlan, C. Jeandel, F. Lacan, L. Meynadier, P. Montagna, A. M. Piotrowski, Y. Plancherel, E. Pucéat, M. RoyBarman and C. Waelbroeck, Chem. Geol., 2017, 457, 131-148.

J. L. Banner, Earth-Science Rev., 2004, 65, 141-194.

S. B. Jacobsen and G. J. Wasserburg, Earth Planet. Sci. Lett., 1980, 50, 139-155.

C. H. Evans, Biochemistry of the Lanthanides, Plenum Press, New York, 1990.

W. M. White, J. Patchett and D. BenOthman, Earth Planet. Sci. Lett., 1986, 79, 46-54.

K. T. Rim, K. H. Koo and J. S. Park, Saf. Health Work, 2013, 4, 12-26.

B. Wei, Y. Li, H. Li, J. Yu, B. Ye and T. Liang, Ecotoxicol. Environ. Saf., 2013, 96, 118-123.

R. Pietra, E. Sabbioni, L. Ubertalli, E. Orvini, G. Vocaturo, F. Colombo and M. Zanoni, J. Radioanal. Nucl. Chem., 1985, 92, 247-259.

36 S.-L. Tong, W.-Z. Zhu, Z.-H. Gao, Y.-X. Meng, R.-L. Peng and G.-C. Lu, J. Environ. Sci. Health. A. Tox. Hazard. Subst. Environ. Eng., 2004, 39, 2517-2532.

Y. Ming and L. Bing, Spectrochim. Acta Part B, 1998, 53, 1447-1454.

X. Li, Z. Chen, Z. Chen and Y. Zhang, Chemosphere, 2013, 93, 1240-1246.

S. Zaichick, V. Zaichick, V. Karandashev and S. Nosenko, Metallomics, 2011, 3, 186-194.

G. Vocaturo, F. Colombo, M. Zanoni, F. Rodi, E. Sabbioni and R. Pietra, Chest, 1983, 83, 780-783.

41 P. Collecchi, M. Esposito, S. Meloni and M. Oddone, J. Radioanal. Nucl. Chem., 1987, 112, 473479.

42 K. Inagaki and H. Haraguchi, Analyst, 2000, 125, 191-196.

43 M. Esposito, M. Oddone, S. Accardo and M. Cutolo, Clin. Chem., 1986, 32, 1598.

44 C. Koeberl and P. M. Bayer, J. Alloys Compd., 1992, 180, 63-70.

45 P. Vos, Origin of the Dutch Coastal Landscape. Long-Term Landscape Evolution of the Netherlands During the Holocene, Described and Visualized in National, Regional and Local 
Palaeogeographical Map Series., Barkhuis Publishing, Eelde, 2015.

46 G. Van der Veer, in Netherlands Geographical Studies 347, eds. J. G. Borchert, J. M. M. Van Amersfoort, H. J. A. Berendsen, P. C. J. Druijven, A. O. Kouwenhoven and H. Scholten, Koninklijk Nederlands Aardrijkskundig Genootschap, 2006.

47 G. Bayon, S. Toucanne, C. Skonieczny, L. André, S. Bermell, S. Cheron, B. Dennielou, J. Etoubleau, N. Freslon, T. Gauchery, Y. Germain, S. J. Jorry, G. Ménot, L. Monin, E. Ponzevera, M. L. Rouget, K. Tachikawa and J. A. Barrat, Geochim. Cosmochim. Acta, 2015, 170, 17-38.

48 G. Kuhlmann, P. L. de Boer, R. B. Pedersen and T. E. Wong, Sediment. Geol., 2004, 171, 205-226.

49 L. M. Kootker, R. J. van Lanen, H. Kars and G. R. Davies, J. Archaeol. Sci. Reports, 2016, 6, 1-13.

50 J. M. Koornneef, I. Nikogosian, M. J. van Bergen, R. Smeets, C. Bouman and G. R. Davies, Chem. Geol., 2015, 397, 14-23.

51 J. M. Koornneef, C. Bouman, J. B. Schwieters and G. R. Davies, J. Anal. At. Spectrom., 2013, 28, 749-754.

52 J. M. Koornneef, C. Bouman, J. B. Schwieters and G. R. Davies, Anal. Chim. Acta, 2014, 819, 49-55.

53 M. Griselin, J. C. Van Belle, C. Pomiès, P. Z. Vroon, M. C. Van Soest and G. R. Davies, Chem. Geol., 2001, 172, 347-359.

54 S. Timmerman, J. M. Koornneef, I. L. Chinn and G. R. Davies, Earth Planet. Sci. Lett., 2017, 463, 178-188.

55 M. Klaver, R. J. Smeets, J. M. Koornneef, G. R. Davies and P. Z. Vroon, J. Anal. At. Spectrom., 2015, 31, 171-178.

56 M. Willmes, L. Kinsley, M.-H. Moncel, R. A. Armstrong, M. Aubert, S. Eggins and R. Grün, J. Archaeol. Sci., 2016, 70, 102-116.

57 G. Tyler, Plant Soil, 2004, 267, 191-206.

58 S. J. Goldstein and S. B. Jacobsen, Chem. Geol., 1987, 66, 245-272.

59 S. Kulaksiz and M. Bau, Earth Planet. Sci. Lett., 2013, 362, 43-50.

60 M. J. Kohn, M. J. Schoeninger and W. W. Barker, Geochim. Cosmochim. Acta, 1999, 63, 27372747.

61 T. J. Hayley, J. Pharm. Sci., 1965, 54, 663-670.

62 D. W. Bruce, B. E. Hietbrink and K. P. DuBois, The acute mammalian toxicity of rare earth nitrates and oxides, 1963.

63 L. A. Chesson, J. R. Ehleringer and T. E. Cerling, in Handbook of Environmental Isotope Geochemistry, ed. M. Baskaran, Springer Science \& Business Media, 2012, pp. 707-723.

64 L. O. Valenzuela, L. A. Chesson, G. J. Bowen, T. E. Cerling and J. R. Ehleringer, PLoS One, 2012, 7, e34234. 
65 J. A. Lee-Thorp, Archaeometry, 2008, 50, 925-950.

66 K. Jaouen, P. Szpak and M. P. Richards, PLoS One, 2016, 11, 1-13.

67 J. Birchall, T. C. O'Connell, T. H. E. Heaton and R. E. M. Hedges, J. Anim. Ecol., 2005, 74, 877-881.

68 J. Lewis, A. W. G. Pike, C. D. Coath and R. P. Evershed, STAR Sci. Technol. Archaeol. Res., 2017, 3, 53-65. 